\title{
School Based Management at SD Negeri 245 Palembang
}

\author{
Tini Ernawati ${ }^{* *}$, Happy Fitria ${ }^{2}$, Achmad Wahidy ${ }^{2}$
}

\author{
${ }^{1}$ SD Negeri 245 Palembang \\ ${ }^{2}$ Universitas PGRI Palembang \\ Corresponding author. E-mail : tiniernawati230971@gmail.com
}

\begin{abstract}
The purpose of this study was to determine the extent to which school-based management was implemented in terms of the quality of teaching staff in improving the quality of education. So according to the purpose of this study. So in this study the researcher used a qualitative descriptive approach, while the unit of analysis in this study was SD Negeri 245 Palembang and the informants were selected purposively with data collection techniques through interview, observation, and documentation instruments. The results of the study found that the implementation of school-based management and efforts to improve the quality of teaching staff in improving work professionalism that must be displayed by teachers at SDN 245 Palembang, it can be concluded as follows: First, School Based Management or management of all school resources carried out together by the school community at SDN 245 Palembang in general, it has not been running optimally. Second, the quality of the teaching staff on duty at SDN 245 Palembang, basically in formality has shown adequate competence because it is viewed from the perspective of educational background.
\end{abstract}

Keywords : School Based Management, Quality of Teaching, School Community

\section{INTRODUCTION}

The quality of teachers, which is confirmed to greatly affect the quality of education, needs special attention from the Government, and the Government through its lower level government apparatus, namely the District / City Education Office, as well as units administering education authority and affairs must design policy patterns capable of encouraging school management with the best possible. A classic problem that still occurs in many regions is that the quality of teacher competence in schools is still not optimal according to the needs of modern education. Likewise, in the context of elementary schools within the Palembang City Government, most of them still experience a similar problem, namely the quality of the competence of educators which is expected to not be able to display learning performance in schools effectively. This fact is captured from the opinions and comments of education observers in the mass media, and based on the awareness of educators who feel they still need the development of teaching skills and learning insights to support service as unsung heroes. The analysis put forward by Fitria [1] states that the important role of the principal is very decisive in monitoring and coaching the attitudes, behavior, and development of teacher competence, in order to assess the extent of teacher work motivation to carry out their duties as educators.

Aswanita [2] in relation to the results of observations or observations on the condition of the 245 Palembang Elementary School, that there are problems related to school governance or management, on the one hand, and on the other hand, the quality of teaching staff needs to be continuously improved to support the improvement of the quality of education. The various problems faced as intended are of course also faced by most school institutions, and for the context at SDN 245 Palembang it is estimated that the result is not optimal implementation of school-based management, and it is hoped that the ability to apply a more comprehensive and well-planned concept of school-based management can solve the problem. or at least improve the governance of various aspects relating to school progress.

\section{METHODS}

In accordance with the purpose of this study was to determine the extent to which school-based management was implemented in terms of the quality of teaching staff in improving the quality of education, the researchers used a qualitative 
descriptive approach, while the unit of analysis in this study was SD Negeri 245 Palembang and informants were selected purposively (purposive sampling. ) namely subjects who master the problems according to the research topic. While the data collection techniques are through interview, observation, and documentation instruments.

There are several steps taken by researchers in order to collect data, namely consisting of the following activity processes:

\subsection{Participatory Observation}

In this observation, the researcher is involved with the daily activities of the person being observed or who is used as a source of research data. While doing research, researchers participate in doing what the data sources are doing.

In accordance with this research, the research locus is SDN 245 Palembang, so in the stage of entering the research location, the researcher has several strategic considerations, namely that the research location is essentially rich with phenomena that are able to provide adequate information. Besides this, researchers are more active in searching for both primary and secondary data, namely those that get directly from resource persons and secondary data, namely data that comes from documents.

\subsection{Descriptive Observations}

Descriptive observation can be done by researchers when entering certain social situations as the object of research. At this stage the researcher has not brought up the problem to be studied, so the researcher conducts a general and thorough exploration, describes everything that is seen, heard, and felt.

The main data source for qualitative research lies in words and actions, the rest is additional data such as documents and others.

\subsection{Focused Observation}

At this stage the researcher has carried out a mini-tour observation, which is an observation whose scope has been narrowed to focus on certain aspects.

This focused observation was carried out by direct observation and experience while teaching SD Negeri 245 Palembang as the object of research. This activity is carried out by directly observing the phenomena that occur in the learning process.

\subsection{Selected Observations}

Called selected observations, at this stage the researcher has outlined the focus found, so that the data is more detailed and the researcher is able to find characteristics, differences and similarities between categories, as well as relationships between categories of data being analyzed.

\subsection{In-depth Interview}

Interview data were obtained by conducting direct interviews with relevant officials. Interviews were directed at searching for primary data carried out in depth on selected informants.

Interviews were conducted with informants and resource persons as follows: (a) Secretary of the Palembang City Education Office; (b) Korwil VI District Education; (c) Principal; (d) Teachers who are considered competent.

\section{RESULTS AND DISCUSSION}

The principle of education is regulated in Article 4 of Law Number 20 of 2003 concerning the National Education System sixth paragraph which states : "Education is held by empowering all components of society through participation in the organization and quality control of educational services".

The fulfillment of a match between the abilities of teaching staff and the needs of teaching assignments is a prerequisite for the formation of professional teachers. This means that the skills and abilities of educators reflect the direction and goals to be achieved in the learning process at school. If a school strives to provide excellent educational services, the school bases professionalism on the learning objectives to be achieved.

In view Fathurrochman [3] it is explained that what is meant by professionalism is as follows : "The ability to plan, coordinate and carry out its functions efficiently, innovatively, flexibly, and has a high work ethic."

According to this opinion, the ability of the teaching staff is more defined as the ability to understand the material to be taught, the ability to take necessary steps with reference to the learning mission to be achieved and the ability to improve students' ability to absorb learning material efficiently, make innovations that are not bound to administrative procedures, flexible, and has a high work ethic in supporting the quality of education.

Other views such as [4] state that what is meant by professionalism is: "Reliability in carrying out tasks so that they are carried out with high quality, on time, carefully, and with procedures that are easy to understand and follow by customers".

The formation of professional educators according to the above opinion requires specific knowledge and skills that are formed through education and training as an updating instrument. Fathurochman [5] With special knowledge and skills possessed by educators, it is possible for them to carry out their duties and provide educational services with high quality, on time, and with simple procedures. The formation of abilities and expertise must also be followed by climate change in the world of education which tends to be dynamic and flexible.

Ristianti [6] in addition, in an article entitled Implementation of School Based Management at 
Public High Schools i 5 Banda Aceh (in the Journal of Educational Administration at Syiah Kuala University - Banda Aceh; 2016), written by Aswanita Usman, Cut Zahri Harun, and Murniati, the conclusion is that:

a. Implementation of School Based Management in the field of curriculum management at SMA Negeri 5 Banda Aceh is implemented according to the operational curriculum;

b. School Based Management in the field of student affairs is carried out by planning new student admissions, student orientation period activities, assigning students to certain classes according to achievement, attendance, and controlling student discipline in schools;

c. The application of school-based management in the personnel sector at SMA Negeri 5 Banda Aceh, namely in the management of recruitment is regulated by the local government, the principal only carries out activities and fostering the professional ability of teachers

d. Implementation of School-Based Management in financial management at SMA Negeri 5 Banda Aceh in financial management is carried out by determining the source of funds, analyzing needs, budget allocation, monitoring and reporting by involving school stakeholders;

e. School-based management in the field of public relations at SMA Negeri 5 Banda Aceh is a harmonious relationship between schools and the community the increasing importance of education is felt. This harmonious relationship will form mutual understanding between schools, parents, communities, and other institutions in society.

As the research focus stipulated in the writing of this thesis is school-based management in terms of the quality of teacher professionalism, namely understanding the condition of the competence of teachers or teaching staff as a very determining factor in improving the quality of learning, so analysis is sharpened by referring to writing in scientific publications. The articles that are very relevant include articles in scientific journals entitled Efforts to Improve Teacher Competence through Classroom Action Research Training. This paper was compiled and published by Happy Fitria, Muhammad Kurniawan, and Nur Rahmat (Scientific Publications, Google Scholar; 2019), who recommended in the form of suggestions that a professional teacher must always develop himself to meet the demands of his duties as an educator.

The implementation of school-based management and efforts to improve the quality of teaching staff in improving work professionalism at SDN 245 Palembang, it was found several facts that first, school-based management or management of all school resources carried out jointly by the school community at SDN 245 Palembang in general has not taken place optimally. Because from the observations made and according to experience while serving at the school, it turns out that there are still several obstacles that hinder the determination of school management (Principals and Teachers) to develop the quality of education. The constraints referred to include the limited school infrastructure in accordance [7]with the demands of the 2013 curriculum, and more importantly the condition of the quality of the teaching staff who have not displayed innovative teaching performance according to the demands of the current learning process. Second, the quality of the teaching staff on duty at SDN 245 Palembang, basically in formality they have shown adequate competence because in terms of educational background most of them are in accordance with the standards of education at the elementary school level. In fact, some of them have shown commitment and determination to serve as educators as well as possible, so that teachers are committed to continuing to learn and be creative in carrying out the learning process. However, the teachers have not been able to find teaching methods that attract students' attention, for example building interactions in class, and using visual / pictorial props, or learning outside the classroom. In addition, teacher communication techniques must also be improved so that students feel comfortable when interacting with their teachers. [8]Teachers are fully aware that they must be able to create and innovate in delivering material, because the demands for quality of education continue to develop, especially the development of information technology which directly requires teachers to be able to adapt to the sophisticated advances in information technology that need to be utilized to support the teaching and learning process.

\section{CONCLUSION}

Steps to improve the quality of education, one of which is also determined by the quality factor of the teaching staff, have begun to be implemented both institutionally and independently by the teachers themselves. The Principal of SDN 245 Palembang is quite active in involving himself and his teachers to attend various seminars and workshops in the field of education organized by the Palembang City Education Office or other organizers. And on the other hand, the school always provides support for the interest of teachers to perform continue undergraduate and postgraduate education through the Study Permit Program. In addition, there is a high motivation for teachers to always think hard, and work smart to support the progress of SDN 245 Palembang.

Sudjiono [9] Therefore, the author tries to recommend several things in order to realize an increase in the quality of teaching staff to achieve the development of the quality of education at SDN 245 Palembang, including (1) preparing teachers 
by taking courses or training and every budget year the school must prepare funds reward (material award) for teachers who are able to present effective innovations to support the learning process; (2) increasing good example and leadership by the Principal, by providing good examples, having authority in front of the teachers in order to foster a communicative interaction pattern; (3) increasing the role of synergistic coordination between Principals, Deputy Principals, School Committees, Guardians and Teachers and other Education Personnel in order to directly monitor the general condition of the school for discussion together to find ways to fix and improve school resources. which needs to[10] be improved to support the improvement of the quality of SDN 245 Palembang schools. (4) Principals should be able to implement a work system and a more communicative personal relationship by directing teachers to be able to develop work creativity related to the delivery method of learning materials, including creating a comfortable atmosphere in the classroom; and (5) more awareness of teachers to increase a high work ethic and discipline in the implementation of teaching tasks, so that teachers are gradually able to improve teaching methods that tend to be passive and monotonous, so that in the future they will be more active, creative, and innovative in carrying out their profession. as a teacher [11] [12].

\section{REFERENCES}

[1] Fitria, Happy. Pengaruh Supervisi Kepala Sekolah dan Motivasi Kerja Guru terhadap Kinerja Guru. Jurnal Manajemen Pendidikan Universitas PGRI Palembang; 2020.

[2] Aswanita, Usman, Implementasi Manajemen Berbasis Sekolah Pada SMA Negeri 5 Banda Aceh. Jurnal Administrasi Pendidikan Universitas Syiah Kuala. Banda Aceh. Vol. 15 No 10 Hal.78. 2016.

[3] Tjokrowinoto, Mujiarto, Pembangunan, Dilema, dan Tantangan, Pustaka Pelajar, Yogyakarta. 2006.

[4] Siagian., \& Sondang, P. Manajemen Sumber Daya Manusia, Jakarta: Bumi Aksara. 2012.

[5] I. Fathurrochman, S. Danim, S. Anwar AB, N. Kurniah, and D. H. Ristianti, "Theoretical Review of the Implementation Islamic Boarding School Curriculum Management in Indonesia,” Int. J. Educ. Res. Dev., vol. 1, no. 1, pp. 1-15, 2021.

[6] I. Fathurrochman, S. Danim, S. Anwar AB, and N. Kurniah, "The School Principals' Role in Education Management at the Regional Level: An Analysis of Educational Policy in the Industrial Revolution 4 . 0," Adv. Soc. Sci. Educ. Humanit. Res., no. 532, pp. 237-242, 2021.
[7] Undang-Undang Nomor 23 Tahun 2000 tentang Sistem Pendidikan Nasional.

[8] Rizky. Interaksi dan Motivasi Belajar Mengajar. Jakarta:Bina Aksara. 2009.

[9] San Fauziya, D. (2018). Pembelajaran Kooperatif Melalui Teknik Duti-Duta dalam Meningkatkan Kemampuan menulis Argumentasi. Riksa Bahasa: Jurnal Bahasa, Sastra, dan Pembelajarannya, 2(2).

[10] Slameto. Belajar dan faktor-faktor yang mempengaruhinya. Jakarta: PT. Renika Cipta. 2010.

[11] Sudijono, Anas. Pengantar Statistik Pendidikan. Jakarta :PT Rajagrafindo Persada. 2000.

[12] D. H. Ristianti, "Analisis Hubungan Interpersonal Mahasiswa terhadap Dosen dalam Proses Bimbingan Skripsi," Islam. Couns. J. Bimbing. Konseling Islam, vol. 1, no. 1, p. 25, 2017. 